\title{
SYTUACJA ROZWOJOWA WSI W WOJEWÓDZTWIE OPOLSKIM W WARUNKACH DEPOPULACJI
}

\section{DEVELOPMENT OF RURAL AREAS IN THE OPOLSKIE VOIVODSHIP UNDER DEPOPULATION CONDITIONS}

\author{
Ryszard WILCZYŃSKI \\ Uniwersytet Ekonomiczny we Wrocławiu \\ ul. Komandorska 118/120,53-345 Wrocław \\ biuroposelskie.wilczynski@gmail.com
}

\begin{abstract}
Zarys treści: W 1975 r. obszary wiejskie województwa opolskiego zamieszkiwało ok. 559 tys. osób, tj. o 13,9\% więcej niż w 2014 r. Ubytek mieszkańców jest nierównomierny. Aż 19 gmin straciło ponad 20\% ludności, a w 6 z nich ubytek przekroczył 30\%. W tym okresie zaledwie kilkuprocentowy wzrost liczby mieszkańców miał miejsce w 5 gminach. Według prognoz w 2050 r. na wsi będzie mieszkać ok. 385 tys. osób - aż o 19,6\% osób mniej niż obecnie. Zmiany będą kontynuacją już ugruntowanych procesów depopulacji trwających od co najmniej czterech dekad. Wyróżnia to województwo opolskie w kraju i predysponuje do bycia poligonem badawczym przekształceń demograficznych oraz pozyskiwania wniosków na rzecz przeciwdziałania nieuchronnym skutkom wyludnienia. Strategia regionu Program Specjalnej Strefy Demograficznej „Opolskie dla Rodziny” nie uwzględnia problemu zanikania jednostek osadniczych, choć skala spadku liczby ludności na obszarach wiejskich proces ten implikuje.

Proces zanikania wsi, zobrazowany w studium przypadku wsi Wilków, odpowiada modelowi negatywnej spirali rozwoju sformułowanemu w Austrii i popularyzowanemu przez G. Weber. Proces ten, po zadziałaniu czynnika wyzwalającego, np. braku pracy, jest sekwencją wielokrotnych negatywnych sprzężeń zwrotnych. Autor wydziela fazy tej sekwencji, wskazując czynniki (transfery finansowe z emigracji zarobkowej i interwencja środków unijnych), które w województwie opolskim spowolniły proces. W latach 2002-2014 spadek liczby mieszkańców objął 3/4 sołectw. Aż w 244 sołectwach był on większy niż 1\% rocznie. W 1/3 sołectw w okresie 2008-2013 nie wybudowano żadnego mieszkania. Liczby te oddają skalę zagrożenia zaniku wsi w regionie. W artykule omówiono również perspektywy dalszych przekształceń wsi w województwie opolskim w zależności od ich typu oraz sformułowano zarysy strategii przeciwdziałania.
\end{abstract}

Słowa kluczowe: spirala negatywnego rozwoju, depopulacja, obszary wiejskie, województwo opolskie.

\section{Wstęp}

Województwo opolskie, jako pierwszy region w Polsce, uznało zagrożenia związane z depopulacją ${ }^{1}$ za kluczowy problem swego rozwoju i zaplanowało przeciwdziałanie z wykorzystaniem środków unijnych z perspektywy 2014-2020. Ramę owych działań stanowi

1 Zob. Problemy Śląska ze szczególnym uwzględnieniem województwa opolskiego wyzwaniem dla ekonomii społecznej, pod red. E. Zagórowskiej, Regionalny Ośrodek Polityki Społecznej w Opolu, Opole 2013. 
Program Specjalnej Strefy Demograficznej (SSD) "Opolskie dla Rodziny”. ${ }^{2}$ Nie uwzględnia on jednak konieczności zmierzenia się z problemem zanikania wsi, pomimo iż zagrażająca funkcjonowaniu regionu skala spadku liczby ludności wymaga uznania oczywistej implikacji: wyludnianie regionu oznacza „kurczenie się” jednostek osadniczych. Te aspekty były konsekwentnie podnoszone przez wojewodę opolskiego. Konferencja Funkcjonowanie obszarów wiejskich w warunkach kryzysu demograficznego, zorganizowana w lutym $2012 r^{3}$, była impulsem do prac nad całokształtem problematyki demograficznej w regionie oraz kierowała uwagę na zagadnienie rozwoju wewnętrznego miejscowości (Wilczyński 2012, 2014, 2015), wprowadzając do dyskursu o rozwoju obszarów wiejskich pojęcie paradygmatu dopasowania ${ }^{4}$.

Zmiany, jakie do 2050 r. zajdą na obszarach wiejskich województwa opolskiego, będą kontynuacją już ugruntowanych procesów trwających od co najmniej czterech dekad. To wyróżnia województwo opolskie spośród innych regionów w kraju. Obecna sytuacja niektórych województw (podlaskie i podkarpackie) skalą i intensywnością wyraźnie przypomina zjawiska, jakie 20-30 lat wcześniej zachodziły na Opolszczyźnie. Z powodu intensywności depopulacji oraz jej wystąpienia wcześniej niż w innych regionach kraju, region opolski ma walor poligonu doświadczalnego. Dokonując ewaluacji charakteru i skutków procesów, można zyskać stosowne wnioski na rzecz przeciwdziałania nieuchronnym skutkom wyludnienia. Niniejszy artykuł wyzwanie to podejmuje.

\section{Depopulacja - kluczowe uwarunkowanie rozwoju i wyróżnik województwa opolskiego}

Przemiany demograficzne stają się pierwszoplanowym czynnikiem determinującym rozwój społeczny, ekonomiczny i przestrzenny w Polsce i w wielu krajach Europy. Dzieje się tak ze względu na zaawansowane skutki migracji, spadku dzietności i starzenia się społeczeństw. Rangę problemu podnosi nieodwracalność zachodzących procesów w perspektywie dziesięcioleci. Skutki przemian demograficznych są szczególnie widoczne na terenach zmarginalizowanych, objawiając się zanikaniem wsi.

Opolszczyzna, wewnętrznie zróżnicowana pod względem narodowościowym - o ludności autochtonicznej bądź napływowej (Rauziński i Szczygielski 2008; Szczygielski 2010), od lat 70. XX w. jest regionem emigracyjnym. Ubytek ludności na skutek emigracji zarobkowej implikowanej autochtonicznym pochodzeniem ludności jest dobrze rozpoznany (Jończy 2010). Początkowe polityczno-ekonomiczne przyczyny emigracji po 1990 r. ustąpiły ekonomiczno-kulturowym5. Miało to poważne skutki dla przekształceń społeczno-go-

\footnotetext{
2 Przyjęty przez Zarząd Województwa Opolskiego 16 września 2014 r. (zob. Specjalna Strefa Demograficzna w województwie opolskim, http://www.ssd.opolskie.pl).

${ }^{3}$ www.opole.uw.gov.pl/konferencja-funkcjonowanie-obszarow-wiejskich-..

4 Zakłada on konieczność reagowania na „kurczenie się” obszarów wiejskich, poprzez dostosowanie do zmniejszającej się liczby ludności infrastruktury, usług publicznych i procesów inwestycyjnych.

5 Podwójne obywatelstwo ok. $1 / 4$ ludności w regionie dawało wolny dostęp do rynku pracy w Niemczech i kształtowało wysokie oczekiwania płacowe. Po przystąpieniem do UE wykształcony w obszarze autochtonicznym wzorzec uzyskiwania satysfakcjonującego standardu materialnego, poprzez migrację zarobkową (lub będąc życiową koniecznością i szansą na aktywność zawodową), zwiększył ponad przeciętną krajową odpływ osób w wieku produkcyjnym (głównie młodych). Województwo, leżąc w zasięgu oddziaływania Wrocławia, silniej też doświadcza odpływu młodzieży.
} 
spodarczych (Jończy 2006, 2008) ${ }^{6}$. Pozytywem był transfer kapitału i know how owocujący rozwojem rodzinnych firm sektora MŚP i modernizacją zabudowy, a negatywem stało się wyludnianie miejscowości. W województwie opolskim rodzi się najmniej dzieci w kraju?, a ludności nadal systematycznie ubywa ${ }^{8}$. Według rejestru meldunkowego region zamieszkuje 1002,4 tys. osób, z tego na obszarach wiejskich 480,5 tys. (GUS, 30.06.2014). Na skutek emigracji zarobkowej rzeczywista liczba mieszkańców to niespełna 900 tys. osób9 w tym ok. 425 tys. na wsi. Potwierdzają to dane w systemie EWUŚ ${ }^{10}$, który w województwie opolskim rejestruje zaskakujaco niską liczbę zaoptowanych - jedynie 825154 osób (dane na 31.12.2014), co oznacza, że stałych mieszkańców województwa jest jeszcze mniej.

W 1975 r. obszary wiejskie województwa opolskiego, w jego ówczesnych granicach ${ }^{11}$, zamieszkiwało 516,6 tys. mieszkańców - o 16,6\% więcej niż obecnie na tym terenie (442,5 tys. - GUS, 30.06.2014). W aktualnych granicach województwa mieszkało wówczas 558,7 tys. osób, tj o 13,9\% więcej niż w 2014 r. (480,5 tys. - GUS, 30.06.2014). Prognozy ${ }^{12}$ zapowiadają szybki spadek liczby mieszkańców regionu - do 902 tys. w 2030 r. i 826 tys. w 2040 r. oraz 745 tys. w 2050 r. Za 35 lat na wsi będzie zamieszkiwać ok. 385,2 tys. osób, stanowiąc ponad połowę ludności regionu - 51,7\% (obecnie 47,9\%). Będzie to aż o 19,6\% (94,4 tys.) osób mniej niż obecnie. W regionie silnie zmieni się również struktura wiekowa ${ }^{13}$.

\section{Zanikanie wsi}

G. Weber (2006, 2008, 2009, 2011a, b, 2012), prezentując problem depopulacji w Austrii, przywołała model zaniku wsi („,kurczenia się” obszarów wiejskich) określany jako spirala negatywnego rozwoju ${ }^{14}$ (ryc. 1).

${ }^{6}$ Zob. też: Migracje zarobkowe z województwa opolskiego. Przyczyny i charakterystyka pracy za granica oraz warunki powrotu., red. R. Jończy, Opole 2007 oraz Społeczne skutki zagranicznych migracji mieszkańców województwa opolskiego - wybrane problemy dzieci i osób starszych., 2013, red. A. Walas, W. Goleński, A. Kijak, K. Mesjasz, Opole.

7 W 1960 r. urodziło się ponad 25 tys. dzieci. Na początku lat 80. rodziło się blisko 20 dzieci na tysiąc mieszkańców. Od 1983 r. do połowy lat 90. liczba urodzeń spadła dwukrotnie. W 2010 r. urodziło się 9163 dzieci, w 2012 r. 8939, a w 2013 r. zaledwie 8227. Dzietność kobiet jest najniższa w kraju. W 2012 r. jej wskaźnik wyniósł 1,146 (w Polsce 1,299), tj. niemal dwukrotnie poniżej poziomu prostej zastępowalności pokoleń.

8 4,3 tys. osób rocznie w latach 2011-2013.

9 Według NSP z 2011 r. blisko 108 tys. mieszkańców regionu to emigranci (56,9 tys. osób pochodzi z terenu wsi). Współczynnik 106 emigrantów na 1000 mieszkańców w województwie opolskim jest najwyższy w kraju.

10 Baza danych Narodowego Funduszu Zdrowia obejmująca pacjentów korzystających z podstawowej opieki zdrowotnej.

11 Bez gmin: Rudniki, Praszka, Gorzów Śl., Olesno, Radłów, Dobrodzień.

12 Prognoza ludności na lata 2014-2050, GUS, 2014.

13 W 2050 r. grupy wiekowe 0-14 lat oraz 15-64 lat będą mniejsze o ok. 44\%. Aż o 75\% wzrośnie liczba osób w przedziale 65-79 lat. Osób najstarczych - w wieku 80 lat i więcej, przybędzie ok. 110 tys., co oznacza przyrost o 140\%. Mieszkańcy w wieku poprodukcyjnym stanowić będą aż 48\% populacji, natomiast dzieci i młodzież (0-14 lat) zaledwie 10\%. Przeciętny wiek mieszkańca regionu będzie wyższy o 15,4 lata i wyniesie 55,6 lat (obecnie 40,2 lata). W 2050 r. będzie zaledwie 4560 urodzeń i aż 10683 zgonów.

14 Rozpoznanie negatywnej spirali rozwoju, implikowanej niekorzystnymi przemianami demograficznymi, spowodowało sformułowanie nowego paradygmatu funkcjonowania obszarów wiejskich - paradygmatu dopasowania. Jego podstawę stanowi stwierdzenie nieadekwatności rozwiązań polegających na dotacyjnym pobudzaniu wzrostu. 


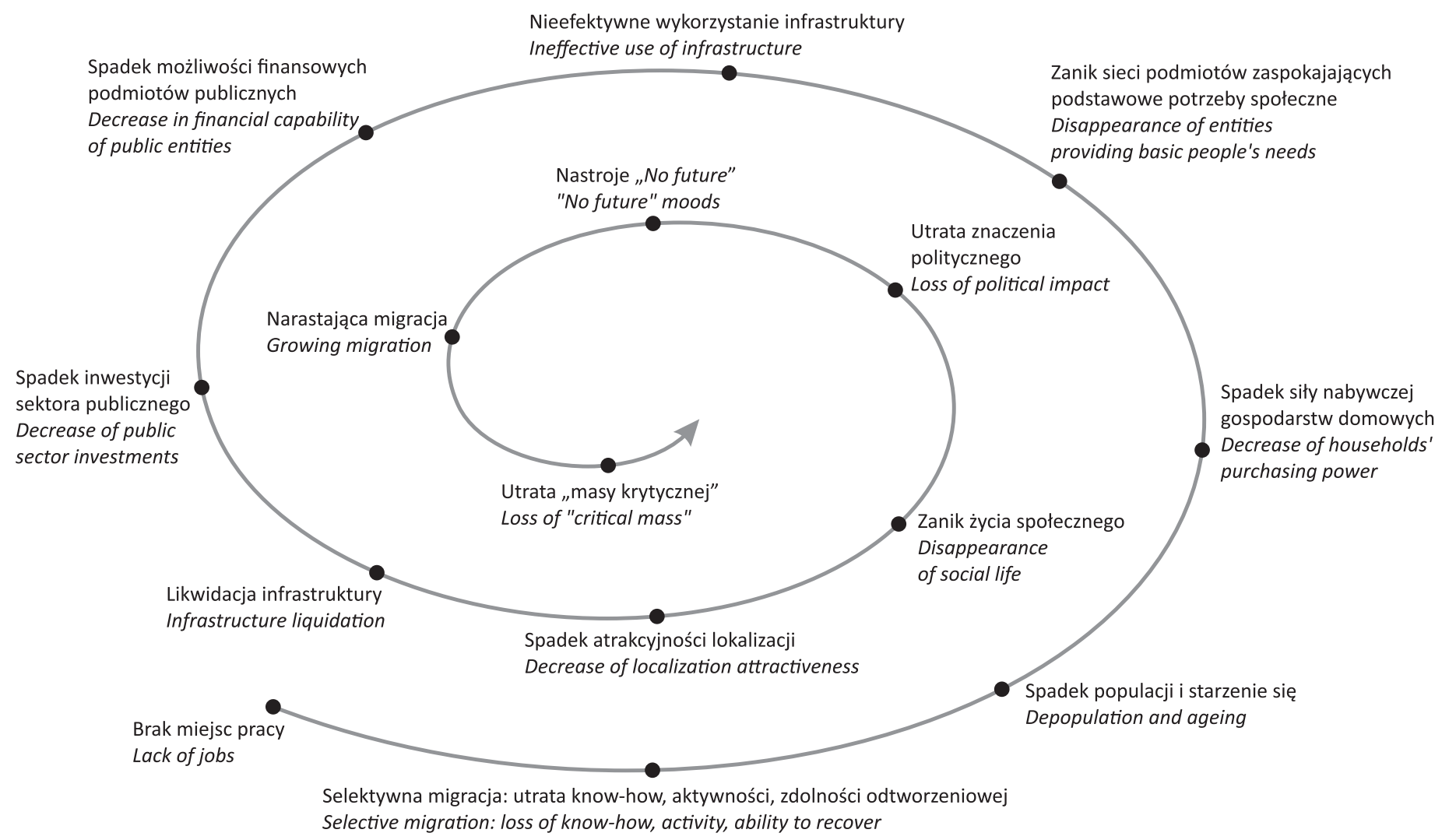

Selective migration: loss of know-how, activity, ability to recover

Ryc. 1. Spirala negatywnego rozwoju

Negative development spiral

Źródło/Source: G. Weber (2011, s. 30). 
Spirala negatywnego rozwoju to scenariusz regresu, a następnie degradacji miejscowości w wyniku spadku liczby mieszkańców oraz zmian w strukturze wiekowej, co prowadzi do zaniku żywotności i utraty niezbędnej do funkcjonowania „masy krytycznej”15. Przebieg procesu ma charakter wielokrotnych negatywnych sprzężeń zwrotnych następujących po zadziałaniu czynnika wyzwalającego, np. niesatysfakcjonujących warunków życia, niedoboru miejsc pracy, niemożności zaspokojenia wysokich oczekiwań życiowych. W przywołanym modelu autor niniejszego artykułu proponuje podział na fazy, uzupełnienia i nowe ujęcie niektórych stanów:

Faza 1 - selektywnego odpływu ludności (spadek know-how i aktywności)

- migracja zwłaszcza osób młodych i wykształconych,

- spadek populacji - ubytek młodych kobiet (potencjalnych matek), dzieci i młodzieży oraz wzrost grupy osób starszych.

Faza 2 - regresu gospodarki lokalnej

- redukcja siły nabywczej gospodarstw domowych wywołana ubytkiem ludności,

- zanikanie podmiotów świadczących zaopatrzenia i usług dla mieszkańców,

- pogorszenie warunków bytowych gospodarstw domowych,

- nieefektywne wykorzystanie infrastruktury,

- zmniejszenie wpływów podatkowych samorządu i wzrost kosztów jednostkowych utrzymania infrastruktury,

- spadek możliwości inwestycyjnych samorządu i nakładów na utrzymanie infrastruktury.

Faza 3 - załamania gospodarki lokalnej i życia społecznego

- brak inwestycji komunalnych,

- likwidacja części infrastruktury,

- nieatrakcyjność miejsca dla lokalizacji działalności gospodarczej i osiedlania się,

- postępujący zanik życia społecznego.

Faza 4 - końcowej migracji

- utrata „znaczenia politycznego” (marginalna pozycja w strategii rozwoju gminy),

- nastroje „no future”,

- nasilona migracja za pracą (brak ludzi młodych, nadmiar starych),

- uzależnienie bytu od transferów socjalnych,

- degradacja substancji budowlanej i pozostałej infrastruktury.

Faza 5 - upadku

- zanikanie tkanki budowlanej, rozpad struktury przestrzennej wsi,

- niesamodzielność życiowa pozostałych mieszkańców.

Według G. Weber końcem negatywnej spirali rozwoju jest stan utraty „masy krytycznej" oznaczający definitywny upadek. Nie wdając się w prawidłowość zarówno pojęcia, jak i jego pozycji w modelu, należy wskazać na moment dużo bardziej istotny - punkt bez powrotu (point of no return), który zapewne dla każdej wsi oznacza inny stan lub zbiór cech. Po jego minięciu praktycznie niemożliwe jest odwrócenie procesów. Nakłady do tego konieczne przewyższyłyby dostępne możliwości (interwencja stałaby się zbyt kosztowną). Przeciwdziałanie procesowi zaniku wsi polega na uruchomieniu mechanizmów dążących

${ }_{15}$ Masa krytyczna (potencjał trwania) jawi się jako funkcja liczby mieszkańców, struktury społecznej oraz wyposażenia decydującego o jakości życia i zakresie zaspakajania potrzeb w miejscu zamieszkania. Widoczną miarą utraty tego potencjału jest wzrastająca liczba pustostanów, brak popytu na nieruchomości i w konsekwencji zanik ruchu budowlanego. 
do zachowania zasady zrównoważonego rozwoju, lecz w warunkach ujemnych wartości kluczowych parametrów wzrostu.

Zbieżne z podanym modelem studium przypadku zaniku wsi prezentuje artykuł Wilków tonie ${ }^{16}$ oparty na relacji sołtysa wsi Wilków w gminie Biała. Żywotna wieś, na skutek długotrwałego oddziaływania splotu regionalnych i lokalnych negatywnych czynników, stopniowo stała się wsią zanikową ${ }^{17}$. Działanie gminy tylko przyspieszyło tempo procesu:

„Za pięć ostatnich lat troje dzieci się urodziło we wsi. Tylko w ostatnim roku zmarło pięć osób, a w styczniu już mamy pierwszy pogrzeb. I były dwa śluby (...). W 1848 roku (...) policzono, że mieszka w Wilkowie 400 osób i (...) 17 parobków (...) pod koniec lat pięćdziesiątych, wioska też liczyła 400 mieszkańców. Teraz dorosłych jest 92. Z dziećmi (...) nieco ponad 110. (...) w 1951 roku (...) we wsi było 30 zakładów, a największy - mleczarnia - zatrudniał 30 ludzi. (...) Było przedszkole, stara i nowa szkoła. Działała poczta, drogeria, dwa sklepy, dwie gospody, szewc, rymarz, dwie stolarnie, 9 zakładów palących wino i gorzałkę, a do tego gospodarska wypalania cegły. (...) Dziś został tylko jeden sklep.

Najpierw w 1979 roku zamknięto szkołę. (...) Dzieci jeszcze były, ale zabrakło kadry (...). Przez następne lata gmina sprzedała budynek starej szkoły, nowej szkoły, przedszkola i jeszcze szkolne boisko, na którym dziś rosną buraki. Na sprzedaż poszedł prawie cały wiejski majątek z poprzednich wieków. Ostatnio (...) piaskownia wiejska przy drodze na Golczowice.

(...) Po likwidacji szkoły ludzie zaczęli wyjeżdżać na Zachód, do Niemiec. Rzadziej do okolicznych miast. (...) Uciekają najmłodsi i najsprytniejsi (...) Jadą całe rodziny, młodzi z dziećmi. Zostaje najstarsze pokolenie. Na 90 dorosłych w Wilkowie 20 osób ma ponad 70 lat. Kto może, dołącza do dzieci (...). Młodzi rodzą dzieci w Niemczech (...). Starsi zdają gospodarstwa na dzieci, żeby załapać się na rentę strukturalną na 10 lat przed wiekiem emerytalnym.

(...) Tu stały trzy domy (...). Przy tej uliczce były cztery gospodarstwa. W tym domu nie ma już nikogo, w następnym także. Co trzecia chałupa we wsi jest pusta. (...) W Wilkowie w ciągu 40 lat rozebrano część domostw, bo rozpadały się, nie remontowane. Znikło 11 gospodarstw. Na 600 hektarach gruntów rolnych we wsi pracuje teraz 9 rolników i Rolnicza Spółdzielnia Produkcyjna z sąsiednich Rostkowic (...). Z domów zostało 87 numerów. (...) Tych niezamieszkanych sprzedać nie można, bo spadki nie uregulowane albo nie ma chętnych. Czasem tylko ktoś z Niemiec znajdzie sobie najemcę na dobrze utrzymany i wyremontowany dom. (...) Jedną zrujnowaną chałupę z ogrodem ma Agencja Nieruchomości Rolnych. Po kilku nieudanych przetargach chce to sprzedać za 10 tysięcy, ale chętnych ciągle brak. Za to miejscowi rolnicy biją się o grunty orne. W ubiegłym roku jeden zapłacił 80 tys. zł za hektar, gdy ktoś sprzedawał 5-hektarowe pole odziedziczone po rodzicach.

(...) Żeby się coś u nas zmieniło na lepsze, we wsi powinno przybyć ze 20-40 młodych mieszkańców. Nie ma na to szans (...). Pracy w okolicy nie ma. Do Opola daleko, Prudnik sam pada. (...) Ludzie we wsi nawet do wyborów nie chcą iść. Są źli, bo starostwo remontowało drogę od Głogówka i Białej. Zrobili nowy asfalt, tylko że przed Wilkowem kończy się z obu stron. Od paru lat nie mogą nam tego uzupełnić."

\footnotetext{
16 Krzysztof Strauchmann, Nowa Trybuna Opolska z 24 stycznia 2014, s. 11-12.

17 Na koniec 2014 r. zameldowane były 172 osoby.
} 


\section{Zagrożenie zanikiem wsi w regionie}

R. Jończy w komentarzu do wyżej przywołanego artykułu (zob. przypis 16) uznał, iż Wilków:

„to typowa wieś autochtoniczna, której mieszkańcy wyjeżdżają do Niemiec od lat osiemdziesiątych. Do tego mała i położona na peryferiach. Spełnia wszystkie kryteria, żeby się wyludnić (...).Władze gmin często tłumaczą swoje decyzje o zamknięciu przedszkola czy szkoły brakiem dzieci. Tymczasem taka decyzja bywa punktem zwrotnym w rozwoju miejscowości. Tylko przyspiesza proces wyludnienia. Po likwidacji infrastruktury wiejskiej nikt się tam nie chce przenieść, a część miejscowych ucieka (...) zostają (...) starzy ludzie, swoiste eurosieroty starszego pokolenia (...) Kiedy ich dzieci wyjeżdżały do Niemiec, mieli po 40-50 lat, byli samodzielni i samowystarczalni. Teraz mają po 70-80 lat i coraz bardziej potrzebują pomocy. (...) Dla lokalnych władz to będzie coraz większy problem - jak zorganizować opiekę dla rozproszonej masy starych ludzi (...) ". Sytuacja Wilkowa [zdaniem R. Jończego] „to (...) problem trzech czwartych małych miejscowości na Opolszczyźnie".

Uznanie przez samorząd województwa spadku liczby ludności Opolszczyzny za kluczowy problem regionu przypada na czas, gdy tempo wyludnienia, według statystyki publicznej, ma wartość ok. 0,5\% rocznie (realnie ok. 1\%). Omawiany Wilków wyludniał się właśnie w takim tempie. Przyjmując, że stan zanikania dotyczy miejscowości, w których liczba ludności w długim okresie systematycznie spada o więcej niż 1\% na rok, trzeba odnotować, iż sytuacja ta jest powszechna w wielu gminach (tab. 1). W okresach 2000-2013 i 2005-2013 przybyło gmin, które osiągają ten wskaźnik. W latach 1975-2013 spadku o ponad 20\% doświadczyło 19 gmin, w tym w 6 z nich w wymiarze ponad 30\%. W gminie Polska Cerekiew ubyło najwięcej mieszkańców - aż 36,21\%.

Tabela 1. Gminy z największym ubytkiem ludności w latach 1975-2013

\begin{tabular}{|c|c|c|c|c|c|c|c|c|}
\hline \multirow{2}{*}{ L.p. } & \multicolumn{2}{|c|}{$1975-2013$} & \multicolumn{2}{|c|}{ 1990-2013 } & \multicolumn{2}{|c|}{ 2000-2013 } & \multicolumn{2}{|l|}{ 2005-2013 } \\
\hline & gmina & $\%$ & gmina & $\%$ & gmina & $\%$ & gmina & $\%$ \\
\hline 1. & Polska Cerekiew & $-36,2$ & Korfantów & $-28,9$ & Branice & $-21,6$ & Cisek & $-14,4$ \\
\hline 2. & Korfantów & $-34,7$ & Polska Cerekiew & $-24,6$ & Polska Cerekiew & $-18,4$ & Branice & $-12,1$ \\
\hline 3. & Baborów & $-33,4$ & Cisek & $-22,7$ & Cisek & $-17,4$ & Leśnica & $-9,2$ \\
\hline 4. & Branice & $-32,8$ & Branice & $-21,4$ & Reńska Wieś & $-15,3$ & Zębowice & $-8,8$ \\
\hline 5. & Cisek & $-31,3$ & Baborów & $-20,6$ & Kolonowskie & $-14,6$ & Polska Cerekiew & $-8,7$ \\
\hline 6. & Pawłowiczki & $-30,4$ & Kolonowskie & $-19,5$ & Leśnica & $-14,5$ & Głogówek & $-7,8$ \\
\hline 7. & Biała & $-28,3$ & Pawłowiczki & $-17,4$ & Baborów & $-13,7$ & Biała & $-7,5$ \\
\hline 8. & Głogówek & $-28,0$ & Bierawa & $-16,8$ & Zębowice & $-13,3$ & Korfantów & $-7,2$ \\
\hline 9. & Kietrz & $-25,8$ & Leśnica & $-16,6$ & Pawłowiczki & $-12,7$ & Baborów & $-7,2$ \\
\hline 10. & Gorzów Śląski & $-25,7$ & Reńska Wieś & $-16,6$ & Murów & $-12,3$ & Pawłowiczki & $-7,0$ \\
\hline
\end{tabular}

Źródło: opracowanie własne na podstawie danych GUS.

W regionie są dwa obszary, w których po roku 1975 ludności ubyło w stopniu przekraczajacym 20\% (ryc. 2). Pierwszy zwarty obszar obejmuje 14 gmin na pograniczu polsko-czeskim oraz w wewnętrznej peryferii regionu pomiędzy gminami: Korfantów 

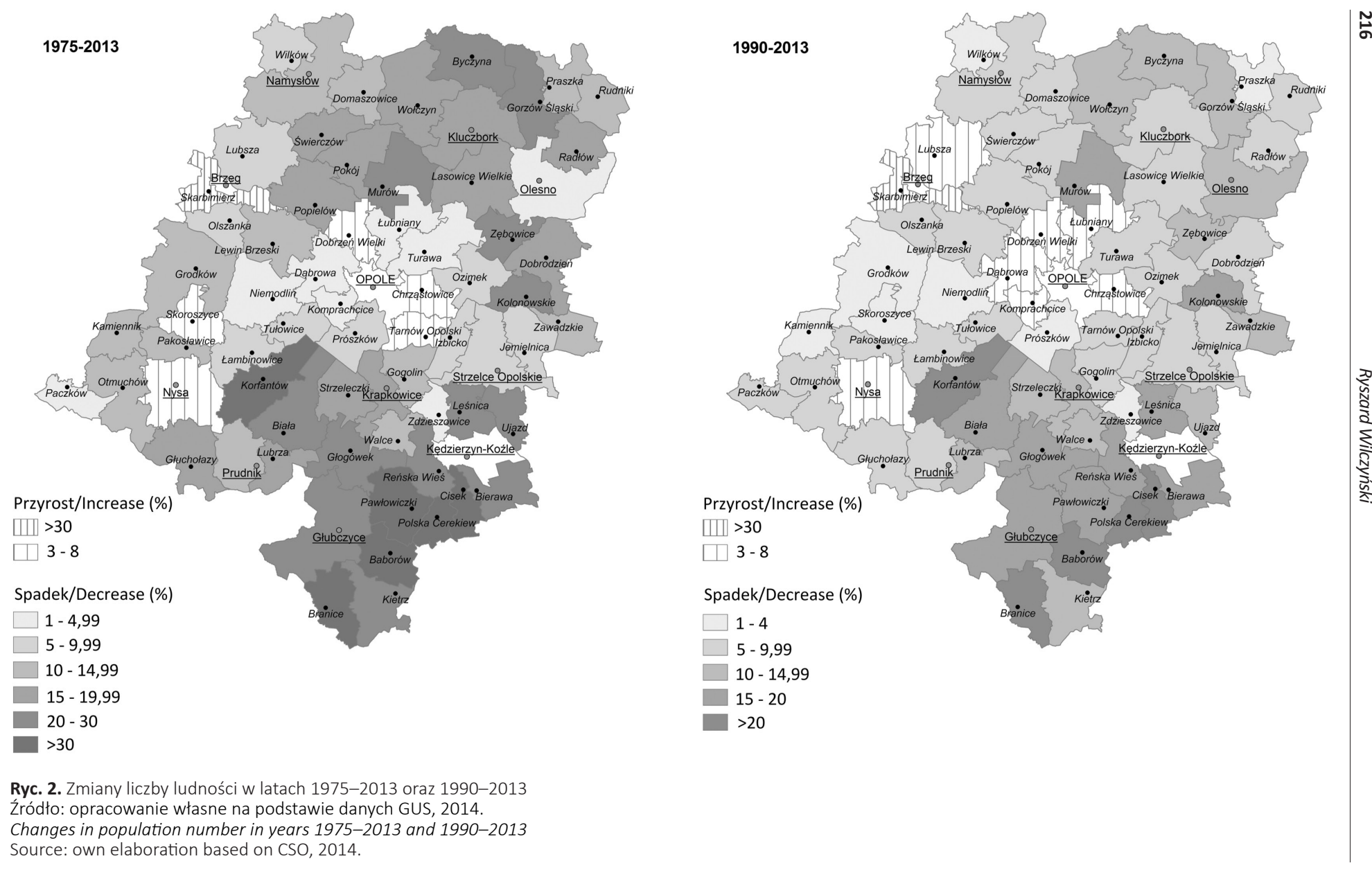

Ryc. 2. Zmiany liczby ludności w latach 1975-2013 oraz 1990-2013

Źródło: opracowanie własne na podstawie danych GUS, 2014.

Changes in population number in years 1975-2013 and 1990-2013

Source: own elaboration based on CSO, 2014. 
na zachodzie, Kietrz na południowym wschodzie, Bierawa na wschodzie oraz Leśnica i Ujazd na północ od Kędzierzyna-Koźla. Drugi obszar obejmuje gminy w północnowschodniej części województwa, zarówno w pasie peryferii wewnętrznej (Murów, Zębowice, Kolonowskie), jak i na pograniczu regionu (Byczyna, Gorzów Śl.). Wyludnienie dotknęło gminy peryferyjnie położone (pogranicze regionu i peryferie wewnetrzne), w zdecydowanej przewadze z ludnością autochtoniczną.

Wzrost liczby ludności na terenach wiejskich w latach 1975-2013 wystapił tylko w kilku gminach i był niewielki (tab. 2). Wyjątkiem jest gmina Skarbimierz ${ }^{18}$ - od jej powstania w 1991 r. liczba ludności wzrosła aż o 43,5\%. Gmin notujacych niewielkie wzrosty liczby ludności po roku 2000 - głównie w związku z suburbanizacją i uprzemysłowieniem - jest zaledwie $8^{19}$. W latach 2005-2013 wzrost zanotowano w 13 gminach, w tym gmina Gogolin, gdzie wyniki przynosi realizacja strategii kreowania wysokiej jakości życia.

Tabela 2. Gminy z najwiekszym przyrostem ludności w latach 1975-2013

\begin{tabular}{|c|c|c|c|c|c|c|c|c|}
\hline \multirow{2}{*}{ L.p } & \multicolumn{2}{|c|}{ 1975-2013 } & \multicolumn{2}{|c|}{ 1990-2013 } & \multicolumn{2}{|c|}{ 2000-2013 } & \multicolumn{2}{|c|}{ 2005-2013 } \\
\hline & gmina & $\%$ & gmina & $\%$ & gmina & $\%$ & gmina & $\%$ \\
\hline 1. & Skarbimierz & 34,54 & Skarbimierz & 43,51 & Skarbimierz & 14,32 & Skarbimierz & 7,76 \\
\hline 2. & Tarnów Opolski & 7,59 & Dobrzeń Wielki & 10,05 & Lubsza & 7,00 & Łubniany & 5,59 \\
\hline 3. & Nysa & 7,07 & Nysa & 6,94 & Nysa & 6,58 & Lubsza & 5,46 \\
\hline 4. & Dobrzeń Wielki & 5,86 & Chrząstowice & 4,04 & Dobrzeń Wielki & 1,81 & Nysa & 5,21 \\
\hline 5. & Skoroszyce & 5,08 & Dąbrowa & 3,73 & Łubniany & 1,39 & Dobrzeń Wielki & 3,07 \\
\hline 6. & Chrząstowice & 3,56 & Łubniany & 2,79 & Dąbrowa & 1,38 & Praszka & 3,05 \\
\hline 7. & & & Komprachcice & 2,45 & Chrząstowice & 1,19 & Zdzieszowice & 2,54 \\
\hline 8. & & & Lubsza & 1,95 & Świerczów & 0,25 & Chrząstowice & 2,34 \\
\hline 9. & & & & & & & Turawa & 1,25 \\
\hline 10. & & & & & & & Gogolin & 1,20 \\
\hline 11. & & & & & & & Olszanka & 0,49 \\
\hline 12. & & & & & & & Dąbrowa & 0,38 \\
\hline
\end{tabular}

Źródło: opracowanie własne na podstawie danych GUS, 2014.

Tendencje spadku liczby ludności obszarów wiejskich agregowane na poziomie gminy w oczywisty sposób są sumą spadku liczby ludności w poszczególnych wsiach, co precyzyjnie ujawnił R. Jończy (2010). Na próbie losowo wybranych 55 miejscowości z terenu województwa potwierdził on powszechnie znany fakt wyludniania się wsi. W tych miejscowościach na początku 2007 r. poziom emigracji zawieszonej wynosił 18,9\% ${ }^{20}$, a w latach 1977-2007 spadek liczby mieszkańców w stosunku do liczby zameldowanych wyniósł 22,2\%. Jednocześnie liczba ludności autochtonicznej zmalała o połowę.

\footnotetext{
18 Zasiedlenie poradzieckiego osiedla mieszkaniowego oraz tereny Specjalnej Strefie Ekonomicznej.

19 Zadziałał czynnik bliskości największych w regionie miast (Opole, Nysa), a w gminie Dobrzeń Wielki motorem wzrostu była budowa elektrowni Opole. Wyjątkiem jest gmina Skoroszyce, w której czynnikiem wzrostu była relatywnie młoda populacja.

20 Faktycznie zamieszkiwało 24708 osób, podczas gdy zameldowanych było 30448 osób.
} 
Autor, bazując na wynikach NSP 2002 i danych z Wojewódzkiego Zbioru Meldunkowego (WZM), ustalił zmianę liczby ludności w sołectwach w latach 2002-2014 (ryc. 3).

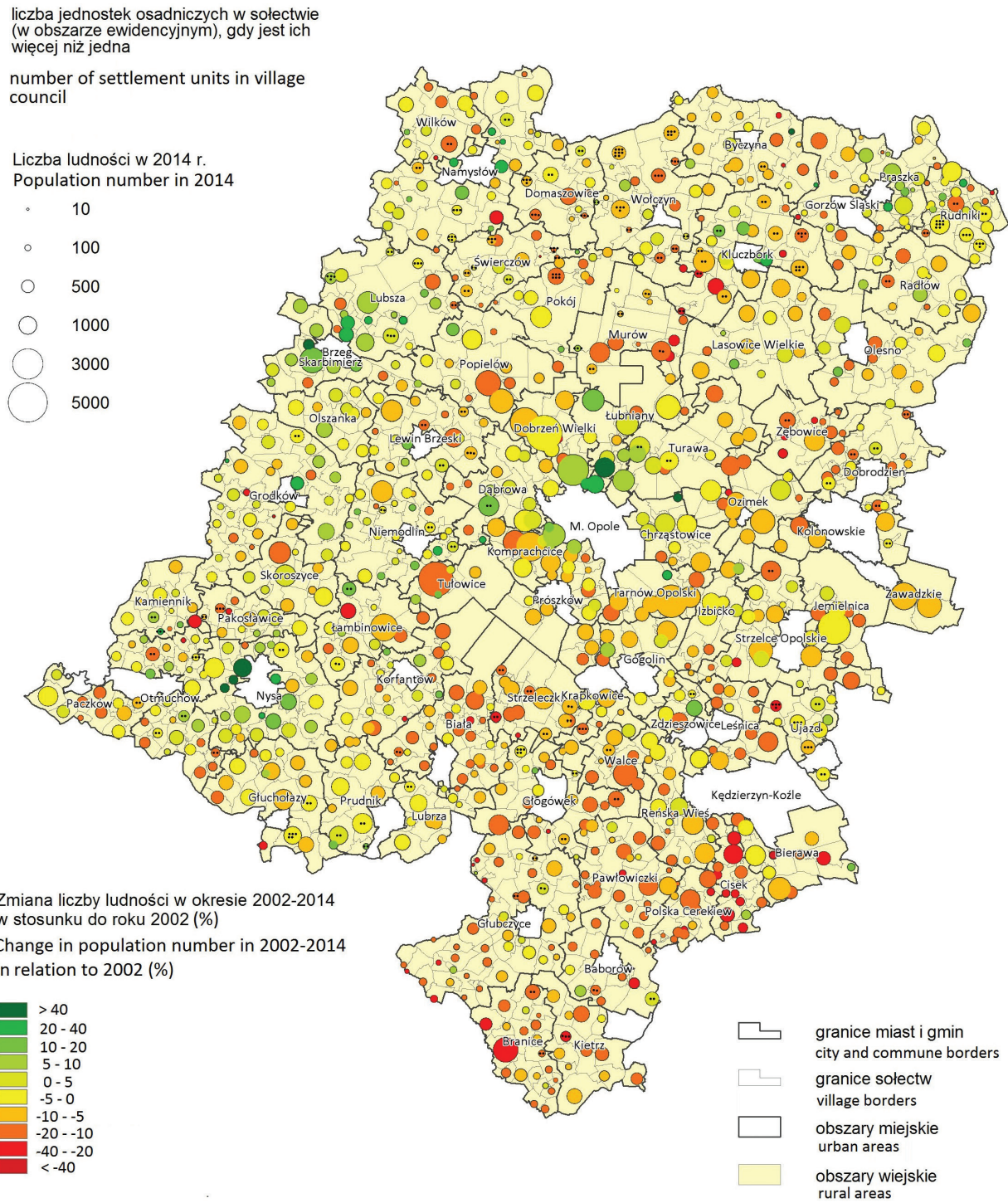

Ryc. 3. Liczba ludności w sołectwach w 2014 r oraz zmiana liczby ludności w okresie 2002-2014 Źródło: Opracowanie własne na podstwie danych GUS (NSP 2002) i WZM, grudzień 2014. Village councils' population number in 2014 and population change in years 2002-2014 Source: own elaboration based on data CSO (National Census 2002) and Voivodship Residence Registry, December 2014.

Odnotowano wzrost liczby mieszkańców w sołectwach otaczających Opole, Brzeg, Nysę i Praszkę. Są wśród nich duże wsie, również takie, w których w podanym okresie liczba mieszkańców przekroczyła 1000. Zjawisko, w mniejszej skali i z udziałem mniejszych 
sołectw, wystapiło pod Namysłowem i Kluczborkiem, także pomiedzy Niemodlinem a Tułowicami, a nie pojawiło w otoczeniu Kędzierzyna-Koźla, Prudnika i Strzelec Opolskich. Ponadto sołectwa z przyrostem ludności rozsiane są na zachodzie regionu poniżej Brzegu (gminy Olszanka, Grodków, Skoroszyce, Pakoslawice, Kamiennik, Otmuchów) - w relatywnie najmłodszej demograficznie części województwa oraz w obszarze większej gęstości zaludnienia (Zdzieszowice - Opole - Ozimek - Zawadzkie). Na terenie województwa rozsianych jest sporo małych bądź bardzo małych sołectw, w których zanotowano dość wysoki przyrost mieszkańców. Łaczy je krajobrazowo-przyrodnicza atrakcyjność lokalizacji, np. obecność dużych zbiorników wodnych.

Spadek liczby mieszkańców dotknął zarówno małe, jak i duże miejscowości, w tym siedziby gmin. W grupie miejscowości o spadku ludności powyżej 1\% rocznie znalazło się aż 12 wsi liczących ponad 1000 mieszkańców lub będących siedzibami gmin²1. Decyduje o tym czynnik autochtonicznego pochodzenia ludności oraz położenie - zarówno fakt speryferyzowania, jak też dostępność aglomeracji. W obu przypadkach jest to czynnik zwiększający odpływ ludzi młodych. Powyżej opisane obszary wyludnienia skupiają większość najsilniej wyludniajacych się wsi, w których w okresie 2002-2014 ubyło ponad 20\% mieszkańców. W ujęciu zgeneralizowanym zmiany liczby ludności w sołectwach obrazuje tabela 3. Wyraźna jest dysproporcja liczebności (3:1) grup spadku i wzrostu ludności. Wolumen ubytku mieszkańców był pięciokrotnie większy niż przyrostu. Głębszy też był spadek - 9,34\%, niż wzrost - 7,7\%. Podane dysproporcje wskazują na słabość i obszarową lokalność czynników wzrostu.

Tabela 3. Zmiana liczby ludności w sołectwach wg grup spadku i wzrostu w latach 2002-2014

\begin{tabular}{|c|c|c|c|c|c|c|}
\hline \multirow{2}{*}{ Lata } & \multicolumn{3}{|c|}{ Spadek } & \multicolumn{3}{c|}{ Wzrost } \\
\cline { 2 - 6 } & liczba solectw & liczba ludności & zmiana & liczba solectw & liczba ludności & zmiana \\
\hline 2002 & \multirow{2}{*}{$777(75,2 \%)$} & 401421 & $\begin{array}{c}-37508 \\
(-9,34 \%)\end{array}$ & $246(23,8 \%)$ & 98852 & $\begin{array}{c}+7608 \\
(+7,7 \%)\end{array}$ \\
\cline { 1 - 3 } & & 363913 & & 106460 & \\
\hline
\end{tabular}

Źródło: opracowanie własne na podstawie danych WZM, styczeń 2015.

W analizowanym okresie 2002-2014 spadek liczby ludności o ponad 1\% zanotowało 746 sołectw (w 2014 r. zamieszkałych przez 348,8 tys. osób). Wzrost o ponad 1\% nastapił w 217 miejscowościach (w 2014 r. zamieszkałych przez 91,7 tys. mieszkańców), a stabilizacja (zmiany w przedziale-1 do $+1 \%$ ) była udziałem 69 wsi (32,1 tys. mieszkańców). Spadek mały (-1 do -5\%) miały 174 sołectwa, średni (-5 do -10\%) 241 sołectw, a duży (-10 do -20\%) 277 sołectw. Aż w 54 sołectwach spadek był jeszcze większy. Spadek liczby mieszkańców większy lub równy 1\%/rok dotknął ok. 240 sołectw, a w ok. 350 miał wartość poniżej średniej (-9,34\% w okresie 12 lat) dla grupy sołectw tracących mieszkańców.

Dla ustalenia sytuacji rozwojowej miejscowości walor diagnostyczny ma mieszkaniowy ruch budowlany (tab. 4). Na opolskiej wsi buduje się bardzo mało. W latach 2008-201322 oddano do użytku 5072 mieszkania. Rocznie mieszkań powstawało mniej niż jest sołectw - najwięcej w roku 2008 - 945, rok później najmniej - 651. W kolejnych latach nastąpił wzrost aż do 917 mieszkań w 2013 r. W 2009 r. - najsłabszym w omawianym okresie, mieszkania do użytku oddano tylko w 274 sołectwach. W 2012 r. oddano do użytku

21 Skorogoszcz, Popielów, Tułowice, Łącznik, Racławice Śląskie, Kadłub, Polska Nowa Wieś, Wilków (pow. namysłowski), Rudniki, Domaszowice, Branice, Zalesie Śląskie.

22 Dane z tego okresu są dostępne w Banku Danych Lokalnych GUS. 
899 mieszkań w 396 sołectwach $^{23}$. Aż w 306 sołectwach w okresie 6 lat nie oddano do użytku żadnego mieszkania, a w kolejnych 195 sołectwach tylko jedno. Zatem sołectwa praktycznie bez ruchu budowlanego stanowią 48,5\% ogólnej ich liczby. Ruch budowlany był minimalny (2-5 mieszkań w okresie 6 lat) w grupie 29,6\% sołectw. Zaledwie w 277 sołectwach $(26,8 \%)$ do użytku oddawano jedno i więcej mieszkań rocznie. Połowa wszystkich oddanych do użytku mieszkań powstała zaledwie w 72 sołectwach (7\% ogółu sołectw), w których, w podanym okresie, zbudowano 15 i więcej mieszkań.

Tabela 4. Ruch budowlany w sołectwach

\begin{tabular}{|l|c|c|c|c|c|c|c|c|c|c|c|}
\hline $\begin{array}{l}\text { Liczba mieszkań } \\
\text { oddanych do użytku } \\
\text { w latach 2008-2013 }\end{array}$ & 0 & 1 & 2 & $3-5$ & $6-10$ & $11-20$ & $21-30$ & $31-50$ & $51-70$ & $\begin{array}{l}135, \\
142\end{array}$ & 210 \\
\hline \multirow{2}{*}{ Liczba sołectw } & 306 & 195 & 132 & 173 & 111 & 64 & 24 & 21 & 4 & 2 & 1 \\
\cline { 5 - 12 }
\end{tabular}

Źródło: opracowanie własne na podstawie danych GUS (Bank Danych Lokalnych).

Lokalizację budownictwa mieszkaniowego na tle zmian liczby mieszkańców w sołectwach (pogrupowano sołectwa w przedziałami spadku/wzrostu liczby ludności) ilustruje ryc. 4, a zanik ruchu budowlanego wraz z pogłębianiem się spadku liczby mieszkańców tab. 5.

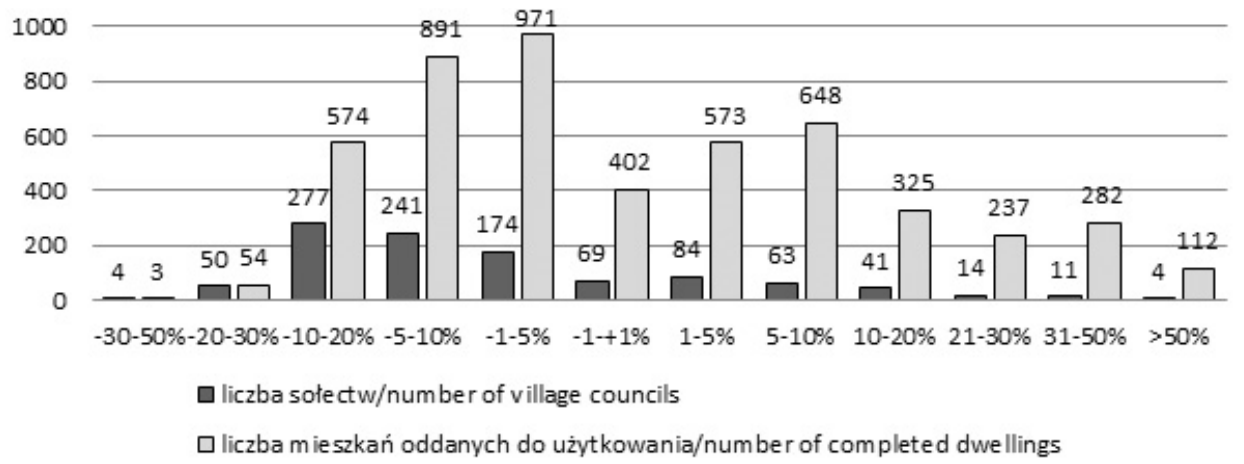

Ryc. 4. Zmiana liczby ludności w sołectwach w latach 2002-2014 a ruch budowlany w latach 2008-2013 Źródło: opracowanie własne na podstawie danych WZM styczeń 2015 i GUS (Bank Danych Lokalnych) Changes in population number of village councils in years 2002-2014 and construction intensity in years 2008-2013

Source: own elaboration based on: Voivodship Residence Registry, January 2015 and CSO (LDB).

Mniej niż jedno mieszkanie na 100 mieszkańców przez 6 lat oddawano do użytku w sołectwach o wyraźnym spadku (poniżej-5\%) liczby ludności w okresie lat 2002-2014. Wyraźny wzrost liczby mieszkańców mają sołectwa, w których współczynnik ten jest dwukrotnie wyższy (ponad 2 mieszkania na 100 mieszkańców w okresie 6 lat). Inna analiza wykazała, iż liczba ludności w sołectwach zaczyna wzrastać powyżej wartości 2,6 oddanego mieszkania na 100 mieszkańców w okresie 6 lat, tj. prawie 0,5 mieszkania na 100 mieszkańców rocznie. okresie.

${ }^{23}$ Była to największa liczba sołectw objętych mieszkaniowym ruchem budowlanym w analizowanym 
Tabela 5. Zmiana liczby mieszkańców a intensywność ruchu budowlanego

\begin{tabular}{|l|c|c|c|}
\hline $\begin{array}{c}\text { Zmiana liczby mieszkań- } \\
\text { ców 2002-2014 (\%) }\end{array}$ & Liczba sołectw & $\begin{array}{c}\text { Mieszkań oddanych do użyt- } \\
\text { ku w latach 2008-2013 } \\
\text { /100 mieszkańców }\end{array}$ & $\begin{array}{c}\text { Mieszkań oddanych } \\
\text { do użytku w latach } \\
\mathbf{2 0 0 8 - 2 0 1 3} \text { /miejscowość }\end{array}$ \\
\hline-30 do-50 & 4 & 0,38 & 0,75 \\
-20 do-30 & 50 & 0,38 & 1,1 \\
-10 do-20 & 277 & 0,53 & 2,1 \\
-5 do-10 & 241 & 0,66 & 3,7 \\
-1 do-5 & 174 & 1,06 & 5,6 \\
-1 do+1 & 69 & 1,25 & 6,2 \\
1 do 5 & 84 & 1,58 & 6,6 \\
5 do 10 & 63 & 2,20 & 10,3 \\
10 do 20 & 41 & 2,08 & 7,9 \\
21 do 30 & 14 & 5,20 & 16,9 \\
31 do 50 & 11 & 6,55 & 25,6 \\
powyżej 50 & 4 & 8,14 & 28,0 \\
\hline
\end{tabular}

Źródło: opracowanie własne na podstawie danych WZM, styczeń 2015 i GUS (Bank Danych Lokalnych).

\section{Perspektywy przekształceń}

W komentarzu do opisu zaniku wsi Wilków R. Jończy (zob. przypis 16) zawarł również prognozę dalszych losów owej zanikowej wsi i nakreślił scenariusz przeciwdziałania, podkreślając jego małą realność z powodu strukturalnej słabości wyludnionego obszaru:

"(...) wioski (jak Wilków) skazane są na wyludnienie (...) zostanie tak zwana reszta folwarczna. Kilka dużych gospodarstw z dużym areałem ziemi. Takie śląskie Bullerbyn z kilkoma zasobnymi rodzinami, które będzie stać na dowożenie dzieci do szkoły w mieście. I może jeszcze ktoś, kto chce spędzić emeryturę w miejscu cichym i spokojnym. Szansą dla małych miejscowości jest jakaś inwestycja, budowa zakładu, ale w Wilkowie raczej do tego nie dojdzie. Za daleko do autostrady, żeby zainteresować inwestora z zewnątrz. Gdyby nawet ktoś miejscowy miał pieniądze i pomysł na biznes, to zaraz pojawi się problem z wykwalifikowanymi pracownikami, bo na miejscu większość to staruszkowie".

R. Jończy wskazał też na względnie stabilną sytuację kilku typów miejscowości:

„Szansę na przetrwanie mają wioski położone wokół większych miast, Opola, Nysy, Krapkowic, które stają się sypialniami bogatszych ludzi pracujących w mieście. Mogą się też utrzymać miejscowości z jakąś lokalną specyfiką, np. turystyczne albo miejsca kultu religijnego, choć (...) wioska Góra św. Anny też się wyludnia. Przetrwają miejscowości liczące co najmniej około tysiąca mieszkańców, gdzie opłaca się utrzymać szkołę, istnieje infrastruktura wiejska, jest kościół, działają sklepy (...) i jest silna społeczność lokalna, działają kluby, koła gospodyń"24.

\footnotetext{
${ }^{24}$ W konkluzji zostało zawarte stwierdzenie, iż sytuacja ta „ „...) nie jest wcale jakąś opolską specyfiką, tylko (proces tu) przebiega nieco wcześniej. Za 20-30 lat podobnie będzie się działo w całej Polsce (...)”.
} 
Można zatem postawić tezę, iż w regionie względnie stabilną sytuację rozwojową mają:

- $\quad$ wsie submiejskie i satelickie miast (grupa 1 - renta położenia). Miejscowości te zyskują mieszkańców z racji intensywnego budownictwa mieszkaniowego;

- $\quad$ duże wsie - czyli wsie będące siedzibą gminy i inne wsie węzłowe (grupa 2 - lokalne centra). Stabilność sytuacji tych miejscowości wynika przede wszystkim ze skali oddziaływania rekompensujący ubytek mieszkańców;

- wsie turystycznie lub w atrakcyjnym otoczeniu (grupa 3 - atrakcyjność przyrodniczo-krajobrazowa). Miejscowości te zyskują mieszkańców na skutek budownictwa mieszkaniowego oraz przejmowania pustostanów;

Pozostałe typy miejscowości należy uznać za problemowe pod względem sytuacji rozwojowej (grupa 4). Są to:

- $\quad$ wsie powiązane funkcjonalnie - miejscowości położone w strefie oddziaływania wsi grupy 2, dobrze z nimi powiązane komunikacyjnie lub/i korzystające z położenia przy głównych drogach. W ramach hierarchicznej sieci osadniczej pełnią funkcje komplementarne lub wyspecjalizowane. Te miejscowości mogą być stabilne dzięki obecności rentownych małych i średnich przedsiębiorstw, znaczących instytucji budżetowych, także efektywnego rolnictwa;

- wsie popegeerowskie, poprzemysłowe - miejscowości poszukujące nowego profilu po utracie dotychczasowej funkcji, z tego powodu cierpiące na brak tożsamości i obarczone poważnymi problemami społecznymi. W sensie przestrzennym są wewnętrznie niespójne, złożone zwykle z tradycyjnej wiejskiej zabudowy i „miejskiego” osiedla pracowniczych bloków mieszkalnych, lokowanego w sąsiedztwie dawnego PGR (często obok dworu i okalającego parku) lub zakładu przemysłowego. Bez nowego profilu rozwoju gospodarczego miejscowości te cechuje wysokie tempo zaniku.

\section{Scenariusze reagowania na wyludnianie wsi}

Niemieckie i austriackie opracowania eksperckie ${ }^{25}$ są zgodne, że najwłaściwszym sposobem reagowania na przekształcenia jednostek osadniczych w wyniku negatywnych przemian demograficznych jest zastosowanie mechanizmów urbanizacji w ramach racjonalnego zagospodarowania przestrzennego. Należy eliminować rozpraszanie zabudowy na rzecz jej koncentracji. W powiązaniu z włączeniem społeczności lokalnej (mobilizacja społeczna i innowacje) i zaangażowaniem eksperckim tworzy to zintegrowane podejście określane pojęciem rozwoju wewnętrznego miejscowości ${ }^{26}$. Jego istotą jest wykorzystywanie potencjału substancji budowlanej, infrastruktury i wolnych przestrzeni wewnątrz miejscowości zamiast prowadzenia procesów inwestycyjnych poza istniejącą zabudową

25 Zob. materiały Obserwatorium Demograficznego: www.opole.uw.gov.pl/obserwatorium-demograficzne

${ }^{26}$ W Bawarii rozwój wewnętrzny rozumiany jest jako szeroko zakrojona strategia budowlanego, funkcjonalnego oraz społecznego rozwoju gminy, która polega na systematycznym ewidencjonowaniu oraz waloryzacji potencjału rozwoju wewnętrznego, ustalaniu istotnych warunków ramowych realizacji przy zastosowaniu zintegrowanych instrumentów rozwoju obszarów wiejskich oraz instrumentów planowania i mobilizacji będących w gestii jednostek samorządu terytorialnego. Zagadnienie rozwoju wewnętrznego szerzej w: Aktionsprogramm Dorf Vital. Innenentwicklung in der Dorferneuerung, München 2011; Vitalitäts-Check. Innenentwicklung als Aufgabe der Dorferneuerung. Dokumentationen, München 2011, 40.- http://www.stmelf.bayern.de 
i tkanką infrastruktury ${ }^{27}$. Na drodze rozwoju wewnętrznego możliwe jest wzmacnianie centrów miejscowości.

Ze względu na nikły ruch budowlany na obszarach wiejskich w województwie opolskim świadome i planowe sterowanie urbanizacją będzie instrumentem dostępnym dla relatywnie małej puli miejscowości zasilanych potencjałem ludnościowym miast.

We wsiach o względnie stabilnej sytuacji rozwojowej (wymienione wyżej grupy 1-3) strategia przekształceń winna ogniskować się wokół wzmacniania centrów i kreacji nowych funkcji (komplementarnych względem miast i obsługowych dla otoczenia) oraz godzenia presji budowlanej z zachowaniem walorów kulturowych miejscowości oraz walorów przyrodniczo-krajobrazowych jej otoczenia. Miejscowości grupy 1, położone w strefie bezpośredniego oddziaływania miast, korzystając z dobrej dostępności komunikacyjnej, mogą kształtować swe funkcje komplementarne w stosunku do ośrodka, który je obsługuje. Duże wsie (grupa 2), jako ośrodki wielofunkcyjne, dość dobrze wyposażone w elementy warunkujące dobrą jakość życia, cechujące się mieszkaniowym ruchem budowlanym oraz na potrzeby działalności gospodarczej, mają możliwość przekształcać się, wykorzystując mechanizmy urbanizacji i odpowiednio ukierunkowanego planowania przestrzennego. Swe funkcje usługowe muszą kształtować pod potrzeby i nowe wyzwania wynikające ze zjawisk wyludniania się ich otoczenia. W szczególności powinny one rozwiązywać problemy związane z usługami publicznymi na rzecz osób starszych. Dla grupy 3 perspektywę wyznacza ich atrakcyjność, która wystarcza dla podtrzymywania inwestycji gospodarczych lub mieszkaniowych oraz tworzy zachętę dla posiadania w nich tzw. drugich domów. Strategia rozwoju tych miejscowości musi koncentrować się na zachowaniu i wzmacnianiu posiadanych już walorów, w czym szczególnie pomocny może być przemyślany plan miejscowy.

W grupie 4 - pozostałych wsi, strategia rewitalizacji przestrzeni i kreowania walorów w powiązaniu z możliwościami wynikającymi z charakteru otoczenia będzie właściwa dla wsi powiązanych funkcjonalnie. Powinno się w nich dążyć do koncentracji zabudowy i utrzymania jej w istniejących granicach terenów przeznaczonych pod funkcje mieszkaniowe. Należy wzmacniać centrum miejscowości, poprawiając wyposażenie w elementy warunkujące jakość życia z uwzględnieniem potrzeb ludzi starszych. Wsie popegeerowskie lub poprzemysłowe winny nastawić się na specjalizację i pozyskiwanie inwestycji sektora MŚP, w szczególności otoczenia rolnictwa, wykorzystując na te funkcje tereny po zlikwidowanych PGR i upadłych przedsiębiorstwach produkcyjnych.

Dla wsi o zaawansowanym zaniku adekwatna będzie strategia odzyskiwania zdegradowanych przestrzeni (popadłe w ruinę pustostany i zakrzaczone działki) oraz poprawa warunków bytowych mieszkańców. Ze względu na brak zainteresowania inwestorów oraz niemożność pozyskania wykwalifikowanych pracowników nie należy zakładać napływu przedsięwzięć inwestycyjnych. Zmiany muszą przede wszystkim prowadzić do poprawy dostępności komunikacyjnej. Efektem rewitalizacji winno być usunięcie zbędnej i zdewastowanej substancji budowlanej. Odzyskanym gruntom należy nadać inne funkcje (nie

${ }^{27}$ W rozwoju wewnętrznym rozstrzygnięcia planistyczne, a następnie ich wdrożenie, ma podstawy w rozpoznanych oczekiwaniach, intencjach oraz możliwościach inwestycyjnych indywidualnych właścicieli nieruchomości. Podejście koreluje z uwarunkowaniami społecznymi i ekonomicznymi oraz zakłada wsparcie gmin i właścicieli przekształcanych nieruchomości. W działaniach na rzecz rozwoju wewnętrznego istotne jest racjonalizowanie usług publicznych, optymalizowanie kosztów i synergia kosztowa. Ważne miejsce zajmuje uwzględnianie potrzeb osób najstarszych, kreowanie rozwiązań na rzecz integracji międzypokoleniowej w przestrzeni publicznej i w budownictwie (domy, osiedla wielopokoleniowe, struktury co-housing). 
wyłączając wykorzystania rolniczego). We wsiach tych należy zachować opcję zabudowy, gdyż waloryzacja przestrzeni może przywrócić im atrakcyjność inwestycyjną. Szansą takich miejscowości są walory środowiska przyrodniczego i krajobrazu zdecydowanie wyższe niż w obszarach presji budowlanej ${ }^{28}$.

Kluczowym problemem jest niemal zupełny brak narzędzi realizacji-obecnie jedynym dostępnym narzędziem jest miejscowy plan zagospodarowania przestrzennego. Miękkim narzędziem realizacji może być strategia rozwoju gminy i tworzona na poziomie sołeckim strategia rozwoju wsi (plan rozwoju miejscowości). Konieczne są nowe instrumenty interwencji:

- $\quad$ organizacja stref aktywności gospodarczej, w których zachętą dla przedsiębiorstw byłby zestaw lokalnych preferencji podatkowych i innych czynników budujących konkurencyjność,

- $\quad$ sądowe uprawnienie gmin do kurateli nad pustostanami (porzuconymi lub bez możliwości przeprowadzenia procedury spadkowej z powodu liczby i rozproszenia spadkobierców) i zagospodarowywania ich (przejęcie na własność gminy po przekroczeniu wartości hipotecznej),

- $\quad$ ustawa o rewitalizacji pozwalająca gminom, również wiejskim, prowadzić proces sanacji wyznaczonych przestrzeni w oparciu o zasady rozwoju wewnętrznego,

- $\quad$ przyjęcie regulacji, na podstawie której kształtowanie wizerunku miejscowości jest zadaniem własnym gminy,

- $\quad$ objęcie wsparciem ze środków unijnych właścicieli nieruchomości istotnych dla kształtowania wizerunku miejscowości oraz właścicieli obiektów o istotnych walorach kulturowych,

- $\quad$ stworzenie preferencji (np. ulgi w VAT) dla inwestorów adaptujących pustostany lub zmieniających funkcję obiektów na mieszkaniowe lub mieszkaniowousługowe w obszarze rewitalizacji podjętej przez gminę.

\section{Podsumowanie}

Zilustrowana skala spadku liczby mieszkańców - skutek emigracji zarobkowej, a w ostatnich latach również starzenia się społeczeństwa i edukacyjnego odpływu młodzieży ${ }^{29}$ (Jończy i in. 2013), zakres ubytku infrastruktury społecznej (na obszarach wiejskich województwa w latach 1994-2010 zlikwidowano 294 szkoły podstawowe) oraz znikomy mieszkaniowy ruch budowlany upoważniają do tezy, iż większość wsi w regionie została dotknięta czynnikiem wyzwalającym negatywną spiralę rozwoju. Duża część z nich, w świetle prezentowanego modelu zaniku wsi, znalazła się w trzeciej fazie zaniku. W obrębie tej fazy należy sytuować „punkt bez powrotu” ${ }^{30}$. W warunkach województwa opolskiego modelowy przebieg procesów zaniku wsi modyfikowały olbrzymie transfery finansowe od migrantów zarobkowych oraz impuls inwestycji realizowanych ze środków unijnych. Dało to długotrwałą stabilizację wsi, głównie autochtonicznych, w obrębie fazy drugiej. Niemniej utrzymanie się wysokiego natężenia spadku ludności nieuchronnie do-

\footnotetext{
28 Przykładem przełomowej zmiany wynikającej z takich walorów wsi może być lokalizacja kompleksu hotelowego w Podlesiu, w gminie Głuchołazy, tuż przy granicy z Republiką Czeską.

${ }^{29}$ Wyjazd na studia jest powiązany z decyzją o opuszczeniu miejsca zamieszkania.

30 W przypadku wsi Wilków była nim likwidacja szkoły.
} 
prowadzi do trzeciej fazy zaniku³. Przyjmując łącznie kryteria: braku infrastruktury społecznej (przedszkola, szkoły podstawowe), braku ruchu budowlanego oraz ubytku liczby mieszkańców (ponad 1\% rocznie), takich wsi jest 150-200. Bez szczegółowych badań nie jest możliwe określenie, jak wiele z nich osiągnęło punkt bez powrotu. Kluczową kwestią jest ustalenie zależności pomiędzy wielkością (węzłowością) wsi, wyposażeniem w zasadniczą infrastrukturę społeczną (ok. $60 \%$ sołectw w regionie jej nie posiada i nie jest także siedzibą parafii) a skalą odpływu ludności. Nie ulega wątpliwości, iż natura wsi zanikowych jest dużo bardziej złożona niż uwarunkowanie peryferyjnością - zanikowi sprzyja niska gęstość zaludnienia w otoczeniu, buforujące sąsiedztwo naturalnych lub administracyjnych granic oraz monofunkcyjność rolnicza ${ }^{32}$. Cytowane badania R. Jończego (2010) wskazują, że determinant należy poszukiwać w pochodzeniu ludności (autochtoniczna / napływowa) i wzorcach zachowań społeczno-ekonomicznych ludności rozwiniętych na tym podłożu. Należy przyjąć, iż zanik wsi ma złożone uwarunkowania oraz odbywa się pod wpływem skłaniającej do migracji strukturalnej słabości miejsca położenia miejscowości sprzężonej z wysysającą siłą oddziaływania metropolii. W polu tych sił wielkość wsi może nie mieć większego znaczenia. Przywołana w przypisie charakterystyka wsi zanikowej jawi się zatem jedynie jako opis jednego ze stanów w modelu spirali negatywnego rozwoju typowego dla przypadku wsi peryferyjnej. Strategie reagowania, wobec systemowego braku narzędzi przeciwdziałania zanikowi wsi, można zaledwie zarysować poprzez pokazanie kluczowych działań, jakie należy podjąć we wsiach zagrożonych tym procesem.

\section{Literatura}

Jończy R., 2006, Wpływ migracji zagranicznych na dysharmonię rozwoju województwa opolskiego (ze szczególnym uwzględnieniem rynku pracy), PIN - Instytut Śląski w Opolu, Opole.

Jończy R., 2008, Zewnętrzne migracje ludności wiejskiej Opolszczyzny po wejściu Polski do Unii Europejskiej. Konsekwencje w kontekście sytuacji społeczno-demograficznej i regionalnego rynku pracy, PIN - Instytut Śląski w Opolu, Opole.

Jończy R., 2010, Migracje zagraniczne z obszarów wiejskich województwa opolskiego po akcesji Polski do Unii Europejskiej. Wybrane aspekty ekonomiczne i demograficzne, PIN - Instytut Śląski w Opolu, Opole-Wrocław.

Jończy R., Rokita-Poskart D., Tanas M., (red.), 2013, Exodus absolwentów szkół średnich województwa opolskiego do dużych ośrodków regionalnych kraju oraz za granicę, PIN - Instytut Śląski w Opolu, Opole.

Rauziński R., Szczygielski K., 2008, Śląska ludność rodzima w strukturze demograficznej i społecznej Śląska Opolskiego wczoraj i dziś, PIN - Instytut Śląski w Opolu, Opole.

Szczygielski K., 2010, Przestrzenne zróżnicowanie ludności województwa opolskiego w kontekście etnicznym jako potencjalne uwarunkowanie rozwoju regionalnego, PIN - Instytut Śląski w Opolu, Opole.

${ }^{31}$ W badaniach należy dążyć do ustalenia parametrów sygnalizujących zbliżanie się i przekroczenie „punktu bez powrotu", co dzieliłoby wsie na silnie zagrożone zanikiem i już zanikowe.

32 W literaturze wsie zanikowe to miejscowości, które szybko tracą mieszkańców, utrzymują się głównie dzięki zabezpieczeniu emerytalnemu i transferom socjalnym, nadto są: słabo dostępne komunikacyjnie i odległe od większych ośrodków miejskich, bez ruchu budowlanego, z nikłą infrastrukturą społeczną i słabym wyposażeniem warunkującym jakość życia; stan substancji budowlanej jest zły, liczne są też pustostany a zagospodarowanie przestrzenne pogarsza się. 
Weber G., 2006, Schrumpfung als Aufgabe der Raumplanung - eine Annäherung aus österreichischer Sicht, Maszynopis.

Weber G., 2008, Schrumpfung - die Herausforderung für eine wachstumsfixierte Raumplanung, [w:] Goldkronacher Gespräche zur Regional- und Kommunalentwicklung, Sonderheft der Schriftenreihe Materialien zur Regionalentwicklung und Raumordnung, Technische Universität Kaiserslautern, Lehrstuhl Regionalentwicklung und Raumordnung, 25, 22-23.11.2007, s. 43-48.

Weber G., 2009, Versuch einer praxisnahen Ordnung empfohlener Bodenschutzinstrumente, [w:] E. Hepperle, H. Lenk (red.), Strategies: Patterns, RisksandResponsibilities; Strategien der Raumentwicklung: Strukturen, Risiken und Verantwortung, vdf Hochschulverlag ETH Zürich, Zürich, s. $143-156$.

Weber G., 2011a, Gesundschrumpfen statt Gesundbeten. Schriftenreihe "Club Niederösterreich", Interessensgemeinschaft ländlicher Raum, 6, s. 28-33.

Weber G., 2011b, Schrumpfung - der bline Fleck einer wachstumsfixierten Raumplanung. [Schrumpfung als Herausforderung für ländliche Räume, München, MAR 14-15, 2011] [w:] Lehrstuhl für Bodenordnung und Landentwicklung, TU München, Schrumpfung als Herausforderung für ländliche Räume, Lösungswege, Strategien und Instrumente, s. 37-42.

Weber G., 2012, Aktuelle Herausforderungen ländlicher Räume und ihre Raumbilder prägende Wirkung, [w:] W. Dornik, R. Grasmug (red.), Möglichkeiten / Abhängigkeiten. Strukturwandel in der Südoststeiermark, Schriften aus dem "Museum im Tabor" Feldbach 10, Leykam, FeldbachGraz, s. 173-184.

Wilczyński R., 2012, Jak efektywnie prowadzić rewitalizację i unikać dotychczasowych błędów, Problemy planistyczne - jesień 2012, Zachodnia Okręgowa Izba Urbanistów, Wrocław, s. 5-14.

Wilczyński R. 2014, Przestrzeń wiejska, [w:] Przestrzeń życia Polaków, Stowarzyszenie Architektów Polskich SARP, Warszawa, s. 37-64.

Wilczyński R., 2015, Jak bronić wsi przed depopulacja i zanikiem, Problemy Planistyczne - wiosna 2015, Zachodnia Okręgowa Izba Urbanistów, Wrocław, s. 7-29.

\section{Summary}

In 1975 rural areas in the Opolskie Voivodship were inhabited by approx. 559 thous. citizens, i.e. $13.9 \%$ more than in 2014 . Decrease of population is unequally distributed. Nineteen communes lost more than $20 \%$ of their inhabitants and in six among them the decrease exceeded 30\% ( up to 36.2\%). Only five communes experienced a slight increase of population. According to the demographic prognosis, in 2050 rural areas are expected to be inhabited by approx. 385 thous. people $-19.6 \%$ less than now. These changes are going to be a continuation of the already consolidated depopulation processes, which have started about 40 years ago. Such condition distinguishes the Opolskie Voivodship and predestines it to becoming an experimental ground for demographic transformation research and forming of conclusions to counteract the inevitable impact of depopulation. The regional strategy Special Demographic Zone Programme - 'Opolskie for a family' does not take into consideration the problem of village vanishing, although the existence of such process is implied by the scale of population decrease. The village vanishing process, depicted by the Wilków village case study, corresponds with the model of a negative development spiral, formulated in Austria by G. Weber in 2006. This process after occurrence of an triggering factor, e.g. lack of jobs, manifests itself as a sequence of multiple 
negative feedbacks. The author distinguishes phases of this sequence indicating factors, e.g. financial transfers from job emigration and EU structural funds, which have slowed down the process in the Opolskie Voivodship. Between 2002 and 2012 inhabitants number decrease took place in 3/4 of villages. In 244 villages it exceeded $1 \%$ per year. In 1/3 of villages between 2008 and 2013 no flat was built. These numbers depict to what extent villages in the region are endangered by vanishing. In the final parts of this article perspectives of further rural transformations in the region were discussed and a counteract strategy was outlined. 
http://rcin.org.pl 